\title{
12 Rape in the age of the Internet
}

\author{
Elisabeth Fransson, Trond Martinsen and Elisabeth \\ Staksrud
}

\section{Introduction}

'We who are young today have the whole world in our pockets. The prosecutor didn't understand this. There's something about the words people use, such as "child pornography" and "rape". Perhaps the law lacks words to describe reality. The new reality. This may be a reality that you, who are a bit older, don't understand. There's a new way of communicating. There are other rules'.

- Alex, a young man sentenced to prison for digital rape

A few years ago, Alex, a young Norwegian male, was sentenced to prison for more than one hundred counts of rape. One of these rapes occurred while he was eating dinner with his family. He was accused according to $\$ 192$ of the general civil penal code of 1902, which defines rape as, 'through violence or threatening behaviour, making someone have sexual intercourse with someone else, or to perform acts that correspond to sexual intercourse with oneself'. 1,2

Rape is commonly understood as involving physical, synchronous contact between two or more people: victims and perpetrators. But with the introduction of the Internet in general, and especially social media through the use of direct communication services, several possibilities have emerged for using this technology for rape remotely, either synchronously or asynchronously. At the same time, understanding these crimes has proved challenging, whether in court, in law, or in the development of legislation. While international studies of online sexual crimes have been conducted (e.g. Handyside \& Ringrose, 2017; Henry \& Powell, 2015; Renfrow \& Rollo, 2014; Klettke, Hallford \& Mellor, 2014), researchers have paid little attention to the perpetrators and their stories. In this chapter, we help to fill this gap by analysing the case of Alex, a young man sentenced to several years in a high-security prison after committing a large number of rapes online. We seek to explore how Internet-mediated rape is understood, both by perpetrators and by the court. This understanding includes, but is not limited to, the intrinsic paradox of digital rape: that people can be found guilty of raping someone they have never met, and who may be at 
a location far away. We draw on interviews with Alex and use his story, perspectives and reflections as a starting point. Our hope is to uncover some of the rationales, motivations and complexities that digital technologies have added to sexual abuse and rape situations.

Our analysis is conducted against the theoretical background of computermediated communication (CMC). We discuss how both group and individual interactions differ between face-to-face (F2F) meetings and CMC, and how this situation can contribute to our understanding of digital rape and related sexual crimes. By choosing this theoretical approach, we seek to increase the understanding of rape as a contemporary, mediated phenomenon that transcends spatial and temporal boundaries.

\section{Background: Internet-related sexual crimes}

A large body of international research has contributed to the understanding of Internet-related sexual crimes against children and youths, including the socalled grooming (e.g. Choo, 2009; Finkelhor, Mitchell \& Wolak, 2000; Gottschalk, 2011; Kierkegaard, 2008; Peter, Valkenburg \& Schouten, 2006; Staksrud, 2013; Taylor, 2011; Wolak, Finkelhor, Mitchell \& Ybarra, 2008). Research on sexting - sending or receiving sexually suggestive texts or images via mobile phones and messenger services - has also contributed to a wider understanding of the differences between wanted and unwanted sexual contact and content (e.g. Badenhorst, 2011; Drouin, Ross \& Tobin, 2015; Klettke et al., 2014; Mascheroni, Vincent \& Jimenez, 2015; Van Ouytsel, Walrave, Ponnet \& Heirman, 2015; Wolak, Finkelhor \& Mitchell, 2012). What remains less known is how young people use techniques of persuasion, deception and threats towards children and youths online, as well as young perpetrators' own perspectives on their conduct.

The way in which society views sexual offences in general, and specifically those committed via the Internet, is influenced by the media and how politicians, the police and court systems respond to these crimes. Various national legal systems around the globe are now struggling to establish legislative systems and policy provisions that will ensure universal access to the Internet, manage the international and borderless character of online information and communication, and protect and safeguard users. One of the few areas where international legislative efforts have been motivated and acted upon is the protection of children from online sexual abuse. Relevant key legal international instruments include the UN Convention on the Rights of the Child (CRC) (United Nations, 1989); the CRC's Optional Protocol on the Sale of Children, Child Prostitution and Child Pornography; and the Council of Europe's Convention on Cybercrime (Council of Europe, 2001). These instruments, and other examples, represent a moral and political consensus to protect children from abusive adult practices, including those pursued online.

But previous studies have also argued that these systems, especially national legislation, fall short of understanding and differentiating between various 
online sexual practices. A gap exists in legislation to protect against images of child sexual abuse (i.e. child pornography) and consensual sexual practices, including the sharing of sexual images, between teens (Bulger, Burton, O'Neill \& Staksrud, 2017). For instance, in the US case of A. H. v. the State of Florida (2007), a 16-year-old girl and her 17-year-old boyfriend were charged as juveniles under child pornography laws and sentenced to probation for taking photos of themselves engaging in sexual behaviour and then sharing these images with each other only. Thus,

... despite over a decade of policies related to online child protection, issues of fragmentation, unevenness in implementation and penalties intended for adults applied to minors indicate that the complex nature of the Internet and children's use of it require better informed and holistic approaches to policy and provision.

(Bulger et al., 2017, p. 758)

Underlying this concern is an understanding that online sexual engagement, exploration and even violations among youths are perhaps regrettable, yet very common, practices. For instance, a 2018 study with a representative sample of Norwegian children and youths (age 11-17 years) found that 30\% had received sexual messages (sexting) in the previous year, including half $(49 \%)$ of the 15-17-year olds. When asked about how they felt after receiving sexual messages, 35\% expressed that they felt happy, $41 \%$ did not feel anything in particular (neither happy nor upset) and 14\% were a bit upset; 11\% (mostly girls) said they were very upset (Staksrud \& Ólafsson, 2019).

These findings mean that, to many teens today, the use of Internet content and contact is acceptable for gaining information about and engaging in sexual activities. While there is of course a substantial difference between these often pubescent explorative and exploitative engagements and illegal activities (such as rape and child pornography), such situations do not provide a contextual backdrop to the case we will analyse in this chapter, which is that online sexual engagement among young people is quite common (albeit sometimes illegal) and can result from deception and pressure. When the sexual encounter happens online via the written word or still or moving pictures, the question becomes this: What difference does the technological mediation make? A better-informed and more holistic approach, as Bulger et al. (2017) have called for, needs to include the perspective and stories of perpetrators.

\section{Computer-mediated communication}

Research into $\mathrm{CMC}$ has enabled theorisation into how individual and group interactions differ between F2F and computer-mediated meetings (Kiesler, Siegel \& McGuire, 1984; Siegel, Dubrovsky, Kiesler \& McGuire, 1986). The differences that CMC makes may be summarised briefly as a reduction in social-context information and shared norms of how to communicate (Kiesler 
et al., 1984). These factors may include asynchronous communication, reduced social cues, time- and information-processing pressures, the absence of regulating feedback, dramaturgical weaknesses, a general lack of status and positional cues, social anonymity, varying computing norms and immature senses of etiquette (Staksrud, Ólafsson \& Livingstone, 2013). Another relevant factor is what Walther (1996) describes as hyper-personal communication: a more intimate and desirable communication than one would be able to establish face-toface, combined with anonymity (or even deceit) in online interactions. Such hyper-personal communication is often seen to enhance intimacy in the exchange of information, combined with feelings of close group unity. These factors can produce deindividuation, or 'a weakened ability for an individual to regulate his or her own behavior, reduced ability to engage in rational, longterm planning, and a tendency to react to immediate cues based largely on his or her current emotional state' (McKenna \& Bargh, 2000, p. 61).

Thus, when compared to F2F interaction, anonymity in online interactions is linked to both positive and creative forms of self-expression (e.g. Back, Schmukle \& Egloff, 2008; Derks, Bos \& von Grumbkow, 2008) and to increased testing and displays of non-conforming behaviour and verbal aggression (e.g. Parks \& Floyd, 1996; Ybarra, Espelage \& Mitchell, 2007). Such non-conforming aggressive behaviour can also be sexual, including sexual violence and rape, as is the situation in the case that provides the empirical basis for this chapter.

\section{Digital rape studied through one case}

\section{Methodological approach}

The empirical material we have used in this case study is drawn from an ethnographic prison study on young men in prison (see Martinsen, 2016). ${ }^{3}$ The study included 25 young men between the ages of 18 and 23 who, over a period of three months, had been in custody in a high-security prison in Norway. One of these young men, Alex, was later sentenced to prison for multiple digital rapes. The project was extended for the purposes of this chapter and was focussed only on Alex's case. Three types of empirical material pertinent to his case inform the analysis: (1) interviews with Alex, (2) Alex's diary and (3) court judgements related to his case.

We have had 15 conversations with Alex over a period of three years. ${ }^{4}$ The interviews took place while Alex was in custody, both during the court trial and after his conviction. They were open conversations (Widerberg, 2001) that usually lasted an hour and a half. Notes were taken and checked with Alex during the interviews. After each interview, the field notes were written out in full. Alex has read some of the written transcripts of the interviews. He has also been consulted on earlier drafts of this chapter; this consultation has allowed him to correct any mistakes and to provide feedback and complementary information. He has also read the latest version of the chapter. 
Alex started to write his diary when he was taken into custody. The diary has been used as background information and has provided the co-authors with contextual knowledge. Direct quotes from the diary are not provided in this article. The court judgements, which consist of the sentences related to Alex's case, were provided by Alex himself and were also downloaded from domstol.no, with the permission of the Norwegian Ministry of Justice and Public Security. The interview quotes and judgement extracts in this chapter have been translated and were later edited for maximum clarity in English.

While this chapter is based, to a substantial extent, on Alex's own accounts (as presented in the interviews), combined with the official court judgements, it is not possible to understand these accounts as direct representations of reality (Game, 1991). Alex's accounts, the court judgements and the diary must be analysed as texts produced within a specific culture in relation to a specific law at a certain moment - and from Alex's specific subject position. Thus, the work is in part inspired by a narrative tradition within criminology that focusses on how we construct stories to understand and explain our actions, who we are and our subject position (Sandberg, 2013). We have analysed the interviews, the court judgements, the diary and the texts as culturally embedded texts in an attempt to understand the logic of online sexual activity, and how Alex himself and the courts have made sense of his actions.

\section{Ethical considerations}

As researchers in the social sciences, we adhere to Norwegian national guidelines for research ethics in the social sciences, humanities, law and theology, as described by Norway's national ethics committees (see www.etikkom.no). The use of Alex as the only case demands that we as researchers follow the national guidelines for research ethics on free and informed consent and confidentiality, and that we ensure that the relationship between the researcher and the research subject will be built on human dignity and privacy, as stated in the guidelines.

Before we conducted the analysis, we ${ }^{5}$ applied to the Norwegian Centre for Research Data (NSD, from Norsk senter for forskningsdata) to extend the research project. The change involved inviting one of the already-participating informants, Alex, becoming a key informant in the chapter. NSD approved the extension, provided that new informed consent would be secured from the informant. An informed consent requires that informants understand what they are asked to participate in, what types of issues and questions they will be asked, and the potential consequences of their participation, including questions of anonymity. The consent must also be given freely, and in an informed and explicit manner.

In Alex's case, the extended part of the research represented a new topic. We provided Alex with explicit information about the intention of the work described in this chapter, and specifically how we wanted to work with his particular case. We informed Alex that we wanted to use his story as the only 
narrative in an article, and that the second co-author would continue to interview him, with a focus on the digital rapes he had been convicted of. He was also informed that the first co-author would read and analyse the transcripts from the interviews together with the second co-author. Alex was later informed when the third co-author was invited to join the research project, and he accepted the new authorship situation.

In order to be ethically sound, consent must also be given freely, which means that the consent must be obtained without external pressure or constraints on one's individual freedom. What constitutes freely given consent in Alex's particular case is found in the extension of the former research project. To participate in the extended project, Alex had to provide new and informed consent. Alex gave his consent with the understanding that only the second co-author would be in contact with him. To allow for the correction of any mistakes and for Alex to further understand the type of research we were conducting, he was given the opportunity to read earlier drafts of this article, in particular the written representations of his story. The ethical consideration of this scenario was that Alex thus became a research subject more than an object of research. On several occasions, Alex has been informed that if he changes his mind, he may withdraw his consent at any time, without suffering any negative consequences.

As researchers, we have done what we can to secure anonymity by excluding a great deal of information and by anonymising the names of prisons, places and court levels. Alex cannot be guaranteed full anonymity, however. ${ }^{6} \mathrm{He}$ understands that he might be identifiable.

Another ethical concern we have considered in the development of this project is researchers' responsibility to include marginal voices in their research. According to Norway's national ethical guidelines for research (Hvinden et al., 2016), we as researchers have a special responsibility to respect the interests of vulnerable and marginalised groups throughout the entire research process. As a prisoner and perpetrator, Alex by definition belongs to a stigmatised group. It is important for prisoners to be able to tell their stories, and it is equally important for researchers to inject newly acquired information into the existing body of knowledge. In our case, we must ask critical questions related to CMC in order to inform our understanding of digital rape and other Internet-related sexual crimes by relevant stakeholders, such as the courts.

In the context of research projects, being ethical means to be aware of what happens on the way during a given project or task (Deleuze \& Guattari, 1987), and every research position implies ethical questions and considerations. The particular ethical dilemmas in this research, from our point of view, has been Alex's position as a prisoner. Being closed up in a prison with little contact with the outside world, prisoners such as Alex often welcome researchers because they provide a break, represent the outside world and allow the possibility to talk openly. The substantial and long-term contact between the second co-author and Alex, including access to his personal diary and his court judgements, could mean that the relationship may have taken on a more 'therapeutic' or 'friend-based' nature that would then make it difficult for Alex to withdraw 
from the project. We have discussed this possibility openly and explicitly with Alex, who has assured us several times of his wish to participate. We are aware that this chapter poses an ethical dilemma related to anonymity, but as long as Alex continues to provide his free and informed consent, we will choose to publish the chapter.

\begin{abstract}
Alex's story
Alex was under 18 when he started to, as described in the verdict, 'abuse others' (Court judgement). Several of the victims were his own age. The abuses went on for several years. After a while, some of the victims reported him to the police, and a year later, he was arrested for rape. The interviews with Alex and the information from Alex's court judgements display how a typical procedure for this activity took place. First, he created different profiles by posing as a girl on different social media platforms, such as Kik, Snapchat, Instagram, Facebook and Skype, among others. In the following dialogue, Alex describes the process:
\end{abstract}

\title{
INTERVIEWER: How did you first get started with the threats?
}

ALEX: The first guy I got in touch with had a girlfriend. In court, he denied ever sending anything to my faked profile. I threatened to send a picture to her. That was the first threat; I was 16 at the time. I created my first profile when I was 15 . The threats started with disagreements, then escalated from there. The disagreements ended, and new contacts were established.

The court judgement refers, in a similar way, to how Alex initially contacted other youths and how the contact changed:

... he then contacted random boys he found on different social media, and, pretending to be a girl, he established contact. Fairly quickly, he and the individual boys started having sexualised conversations online, and pictures were exchanged, including nude photographs and pictures and films depicting sexual acts. The defendant sent pictures of girls he had found online, and, in return, the individual boys sent nude photographs of themselves.

(Court judgement)

The court understood the initial contact as 'quite innocent' and 'normal', but it quickly turned into 'sexualised talk' and the exchange of pictures before developing into threats and pressure to send more photos/film and then perform acts on Skype (Court judgement).

The court noted the pace of the online communication as one factor to consider; another factor was how Alex as the perpetrator had given orders via the Internet to the victims, combined with threats. Alex explained that these orders would also typically include demands to send pictures and/or videos depicting masturbation. Similarly, he asked for live-action masturbation, such as by forcing the victim, through threats of public exposure, to masturbate or 'put on 
a show' in front of him via a camera on Skype. Sometimes such shows included having to follow the perpetrator's continuous written and detailed instructions as to what actions, positions, angles and attire were required and, in some cases, the use of physical objects. For most of the victims, the rapes continued for a long time, as detailed in the court judgements:

Among other things, the victims have been forced to perform degrading sexual acts live on camera, in part by being recorded and watched by [name redacted], who was unknown to them, and by sending sexualised photographs without being in control of what the offender would do with the videos and pictures. Most of the victims endured repeated acts of abuse over a long period: up to a year and a half in some cases. Further, the presentation of evidence has shown that some of the acts lasted for a long time: upwards of an hour and a half. The convicted person ... demanded that the victims make themselves available whenever he wanted them to, including at night.

(Court judgement)

Through the court judgements, we can read how the victims were affected by this behaviour:

[Name redacted] stated that he was gloomy during this period. He found it difficult to go to school and was absent a lot, as he was afraid something might have been published or that his friends might find out about what had happened. As a result, he received a poor grade in conduct and orderliness, and his homework, assignments, and tests were affected. ... There is no doubt that the victims have perceived the defendant's threatening behaviour as frightening and upsetting. Where a rape is committed face to face, the victim has the possibility to react to the attack. In this case, the defendant has appeared as a hidden offender who keeps returning. The victims did not know whether the risk of new acts of abuse was over. The defendant has been an unknown offender; the victims did not know who he was, where he was, or when he might contact them again. They have been living in fear that photographs and films might be published and have had no control over whether new acts with similar threats might be posed again.

(Court judgement)

The court judgement in Alex's case indicates that the court viewed this type of rape, where the victim is coerced by threatening behaviour into performing sexual acts on themselves, as being equal to other instances of rape; in other words, offenders need not be physically present with their victims when the latter perform sexual acts on themselves; there only has to be a causal link between the threatening behaviour and the sexual acts the victims perform on themselves. The Court of Appeal later upheld the sentence, confirming the original court's assessment of the case. 


\section{Becoming a sexual person}

Alex himself has explained his role as an online sexual abuser in the context of becoming a sexual person. For him, his homosexual identity explains this development:

ALEX: I was desperate for contact but didn't know how to [go about it]. I created a profile on an online site for gay men. The site had an 18-plus age limit, but I changed my age back to 15 once I was on the site. I got a lot of responses and chose the youngest one, but he was still much older than me. I went to meet him, and we went to his flat. We watched a film and had sex. He had to tell me what to do, since I hadn't done that before.

INTERVIEWER: Did you feel used?

ALEX: I can't answer that. I felt that I got what I wanted, but at the same time I felt that it wasn't right. But, I felt as if I had to hurry. Something had to happen! INTERVIEWER: So, then you started to fake profiles?

ALEX: Yes, the online site became a textbook for how I could present myself on my profiles. And [the site] became a way of getting in touch with people the same age. (Alex, in interview)

Alex was 15 years and under the age of sexual consent (which is 16 in Norway) when he created his first profile on the online site. He went on to create additional online profiles with different representations of himself. The rationale was, as he says, 'about sexuality'. For Alex, this rationale provides the full explanation of why things happened as they did:

ALEX: I didn't have the one thing I wanted the most. If I'd been a straight 15 -yearold, none of this would've happened. I was young, curious, and ignorant and didn't understand consequences. I don't define myself as a criminal. I have, however, done criminal acts. ... I didn't know what I liked. The web became somewhere I could explore sexuality; [the victims] did that as well. The web becomes a place where you don't have to make a fool of yourself. And everyone's faking. (Alex, in interview)

The online sexual engagement, exploration and offences that Alex became involved with became for him a way to become a sexual person. Like many other youths, he used the Internet as a tool to both gain information about and to engage in sexual activities. One of the key features of online communication is the absence of social cues, which leads to potential deindividuation, where people have difficulty regulating their own behaviour and instead react to immediate cues based on their current emotional state, such as sexual arousal or excitement:

INTERVIEWER: To what extent do you perceive the people you meet online as individuals? 
ALEX: They are individuals, but not unique individuals. They don't really stand out from each other; they're just a bunch of people. There's distance - in both directions. Who initiates the conversation is irrelevant; $90 \%$ want nudes. You don't really get to know each other; you're just curious ...

INTERVIEWER: But what makes you send photos to strangers?

ALEX: It's thrilling with a stranger. You'll never see him again yet are exposed to nudity. It's a trigger. Snapchat was a breakthrough; it's what started this trend. And anyone can respond to it. (Alex, in interview)

Alex's explanation helps to show how, for him, the social context becomes reduced. Everything comes down to one issue: sexual activity on an Internet scene. There is no flirtation, no time to get to know each other, no curiosity about who the other person is; the other person's thoughts, feelings and dreams are irrelevant. Alex perceives the rules as being different from those of the offline world:

INTERVIEWER: Are there different rules for interactions online?

ALEX: There are different rules. You don't flash your dick in the physical world. You don't do that on the street. In the real world there's etiquette. The worst that can happen online is that you get blocked. That goes for how you write, as well. It's insanely upfront. You become less and less polite towards strangers. You get used to interacting with strangers. Everything that happens out there [in the offline world] can be multiplied by ten online. Of course, there's chaos when you stick all sorts of people on one platform - healthy or ill, anything. Chatting for a day or two was enough. You should be well into the online world. It's a lot about excitement.

INTERVIEWER: What do you get in return?

ALEX: It progresses from one piece of clothing to another, really. You take step after step and keep going further. Pushing limits. It gradually becomes less of a big deal. The worst that could happen is that you get a no or get deleted. (Alex, in interview)

As described in CMC theory, the different rules that are acceptable online may not reflect those in the offline world. Any vulnerability or differences associated with class and other social aspects are filtered or absent when transmitted through CMC. These differences may be greater when the recipients are vulnerable children and youths. As described in the court judgements, some boys switched off their computers, while others did not.

As often referred to in theoretical works, CMC also creates the opportunity for selective, or even dreamt up, self-representation. In Alex's case, his profiles were a substantial misrepresentation of his offline self. Most notably, he made the boys he contacted believe that he was a girl:

ALEX: As to my own story, I developed different profiles, which developed over time. Became a part of me. I now see that I had criminal intent. Didn't realise that at the time. I was tricking people. Tricking people into believing 
I was 'her'. And then I saved the photographs. Had images without asking. (Alex, in interview)

According to Alex, he used the Internet to become a young gay man. His online relations became an integral part of his adult sexuality. This way of using the Internet became like a game, with its own logic: 'You lose control, and the inner logic takes over' (Alex, in interview). In his reasoning, living as he was in a sexualised world as a young gay man, but with few known possibilities to explore his sexuality in the offline world, the virtual world became an opportunity more than a criminal activity.

ALEX: To me it wasn't dangerous. We went in and out of situations all the time. What was presented as abuse in the court judgements disappeared when switched to another situation. The police said, 'We're arresting you for rape'. That went over my head. I didn't understand. The media uses the term 'internet abuse'. That makes a distinction between the physical and what is not physical. I believe that makes sense to people. (Alex, in interview)

Thus, what Alex experienced in front of his computer differed from what the court classified as abuse and rape: a situation not dangerous nor illegal, but rather a situation that he could enter and leave as he wished. In addition, the virtual world influenced the way he understood his relationships with the boys he met on various social media platforms. The way he understood and described the situation, power, free will and the victims' feelings all point to deindividuation. As Alex understood the situation, his victims could have simply logged off, but only a few did. He thus 'played' a social game and did not problematise or reflect upon whether or not the boys he met on the Internet shared his understanding of the situation and of communication, despite the fact that he was misrepresenting himself by using fake profiles and posting as a girl.

In addition, the difference in temporal and spatial presence contributed to the blurring of social cues. There is a synchronicity when the offender and the victim have physical contact in a physical rape situation, whereas digital rapes are more often asynchronous. In Alex's case, he would send a request for sexualised pictures to a victim when that person was doing something else, such as sleeping or doing homework. Alex himself would then receive the photos or videos at another time, thus making the de facto rape occur asynchronously in time. Once, he got a 'Snap' (i.e. from the Snapchat platform) while he was eating dinner with his parents:

INTERVIEWER: You told me once that one of the rapes took place while you were having dinner with your parents; can you explain that?

ALEX: That had to do with time. I'd sent the threat an hour earlier, before I got the reply. I got a notification that I'd received a Snap. The rape is complete the moment the response arrives. The fact that a threat was sent defines it as an attempted rape. (Alex, in interview) 
Alex found it strange that some of the young people seemed interested in continuing to have contact with him on the Internet. This made him question if they all felt they had been raped, or if rape was also a construction that was made in court.

INTERVIEWER: You once told me that one of the victims in the case, after complaints had been filed, friended you on Facebook?

ALEX: The first guy I threatened, after a couple of years I sent him an apology. This was after the first police interview - about six months before I was remanded in custody. He immediately replied that he was okay and wanted to be friends on Facebook. [He didn't take any time] to consider. No hesitation. And he proceeded [to send me] some rather sexualised stuff. The guy was awarded a lot of money in court. The log detailing what I'm telling you was presented in court, but I don't feel they made much of a point of it. I think that some people [when they were questioned] were told that a conviction could entitle them to damages. I was convicted of several instances of raping the guy I'm telling you about now. (Alex, in interview)

\section{Court logics}

Previous studies on CMC have shown how communicating via a screen, as compared to F2F, can increase the testing and display of non-conforming behaviour and verbal aggression (e.g. Parks \& Floyd, 1996; Ybarra et al., 2007). Contrasting with Alex's views and descriptions, as presented above, are descriptions of his modus operandi as found in the court judgements. These texts make clear how the court and the victims understood Alex's behaviour as being planned and aggressive sexual behaviour:

The defendant has systematically and cynically taken advantage of each of the victims for his own sexual gratification. During each session, he has presented the individual victims with detailed instructions for participating in humiliating actions, and he has been the one in a position to end the event, or 'approve' it. He tricked the victims by saying it would be the last time, only to return multiple times and demand more. He ignored any plea not to have to do it; nor did he let comments about pain and blood grant the victims reprieve. He made all obey his orders, regarding when, where, and how. He paid no regard to individual boys' needs for sleep or homework, nor to their reluctance. He did not display any sign of empathy towards any of the boys while this was going on .... In their statements, many of the victims have talked about a feeling of powerlessness and of having no choice. They did not know who the offender was, when he might contact them again, or whether he would carry out his threats. Several of the victims even had their images published online. All of the victims expressed fear, difficulty sleeping, social isolation, and poorer school performance.

(Court judgement) 
From Alex's point of view, the sexual interactions were 'like a game'. The court saw this differently. According to the court judgements, the victims read Alex's behaviour as persuasion, deception and coercion:

The abuse of the underage boys has happened in their own homes and in their own private sphere. The victims experienced a situation of overhanging threat that for some lasted up to a year and a half, for others less. Either way, they have all lived with the continued fear of publication since the time of the first threat. He exerted his power over each of the victims, and he has taken advantage of their highly vulnerable age.

(Court judgement)

The concept of rape has become extended in recent years, and both law and court practice now view rape more seriously (Ryltoft Terjesen, 2016). In the introduction to this chapter, we assessed how rape is commonly understood as occurring through physical contact and temporal proximity of two or more people: one or more victims and perpetrators. Throughout history, rape has been linked to the actual physical meeting between victim and perpetrator. While other sexual crimes have been mediated - for instance, the unwanted depiction of nudity through photographs and films - rape as a particular category of sexual crime has been confined to F2F meetings. Against this background, it is interesting to note how one underlying conflict that arises from Alex's court case is the difference in understanding of whether online and offline forms of communication have different embedded qualities and affordances, which again influence how these interactions are understood across generations, structures and texts.

\section{Conclusion}

As previously discussed in this chapter, various studies have shown how online sexual engagement and exploration and even criminal offences among youth are a very common practice, and the borders between pubescent explorative engagements and illegal activities such as digital rape are often blurred. At the same time, digital rape is a serious sexual, often violent, crime that can have devastating and long-lasting consequences for its victims. Alex's case highlights some of the core challenges involved when digital, often generation-specific, transgressive practices cross boundaries, become illegal and encounter the world of courtrooms and legal provisions.

We can see how the courts, Alex and - if we accept the premises of Alex's own story - perhaps the victims themselves perceive the same situations as being serious crimes, but as different types of serious crimes. Thus, rather than offering a conclusion about rape by $\mathrm{CMC}$, as illustrated by the overlapping and contrasting narratives from Alex and the courts, we point to the challenges of providing a research-based approach to policy interventions, legal initiatives and the need to accept the complex nature of CMC. We must also develop a legal 
vocabulary that can be understood and legitimised, both by the Internet generation and beyond.

\section{Notes}

1 Unofficial translation of the Norwegian version of the act, as provided for information purposes by the Ministry of Justice and Public Security. See https://lovdata.no/doku ment/NLE/lov/2005-05-20-28 for the full version of the penal code.

2 In the new Norwegian Penal Code $\$ 291$, rape is defined as (a) having sexual intercourse through violence or threatening behaviour; (b) having sexual relations with someone who is unconscious or for other reasons is unable to oppose the action; or (c), through violence or threatening behaviour, making somebody have sexual intercourse with another, or to perform acts that correspond to sexual intercourse with oneself. The crime is punishable by up to 10 years in prison.

3 This research project has been conducted and financed by the University College of Norwegian Correctional Service (KRUS, for Kriminalomsorgens høgskole og utdanningssenter).

4 One of the co-authors (Martinsen) conducted the interviews.

5 One of the co-authors (Staksrud) was not involved in the application to NSD or in the collection of the empirical data.

6 Going into details on his situation would weaken his anonymity.

\section{References}

Back, Mitja D., Schmukle, Stefan C., \& Egloff, Boris. (2008). How extraverted is honey.bunny77@hotmail.de? Inferring personality from e-mail addresses. Journal of Research in Personality, 42(August 2008), 116-1122. doi: https://doi.org/10.1016/j.jrp.2008.02.001

Badenhorst, C. (2011). Legal responses to cyber bullying and sexting in South Africa. Centre for Justice and Crime Prevention (CJCP) issue paper, 10, 20.

Bulger, M., Burton, P., O’Neill, B., \& Staksrud, E. (2017). Where policy and practice collide: Comparing US, South African and European Union approaches to protecting children online. New Media \& Society, 19(5), 750-764. doi: 10.1177/1461444816686325

Choo, K.-K. R. (2009). Online child grooming: A literature review on the misuse of social networking sites for grooming children for sexual offences. AIC Reports Research and Public Policy Series. Canberra: Australian Institute of Criminology.

Council of Europe. (2001). Convention on Cybercrime. Budapest. Retrieved from http:// conventions.coe.int/Treaty/EN/Treaties/HTML/185.htm

Deleuze, G., \& Guattari, F. (1987). A thousand plateaus: Capitalism and schizophrenia. Minneapolis: University of Minnesota Press.

Derks, D., Bos, A. E. R., \& von Grumbkow, J. (2008). Emoticons in computer-mediated communication: Social motives and social context. CyberPsychology \& Behavior, 11(1), 99-101. doi: 10.1089/cpb.2007.9926

Drouin, M., Ross, J., \& Tobin, E. (2015). Sexting: A new, digital vehicle for intimate partner aggression? Computers in Human Behavior, 50, 197-204. doi: 10.1016/j. chb.2015.04.001

Finkelhor, D., Mitchell, K. J., \& Wolak, J. (2000). Online victimization: A report on the nation's youth. Retrieved from www.missingkids.com

Game, A. (1991). Undoing the social: Towards a deconstructive sociology. Buckingham, UK: Open University Press. 
Gottschalk, P. (2011). Stage model for online grooming offenders. In J. Davidson \& P. Gottschalk (Eds.), Internet child abuse: Current research and policy (pp. 79-103). Abingdon, UK: Routledge.

Handyside, S., \& Ringrose, J. (2017). Snapchat memory and youth digital sexual cultures: Mediated temporality, duration and affect. Journal of Gender Studies, 26(3), 347-360.

Henry, N., \& Powell, A. (2015). Embodied harms: Gender, shame, and technology-facilitated sexual violence. Violence against Women, 21(6), 758-779.

Hvinden, B., Enebakk, V., Fjørtoft, K., Holand, I., Johnsen, R., Kolstad, I., \& Monsen, T. H. (2016). Guidelines for research ethics in the social sciences, humanities, law and theology. Oslo: Norwegian National Committees for Research Ethics.

Kierkegaard, S. (2008). Cybering, online grooming and ageplay. Computer Law \& Security Report, 24(1), 41-55. doi: 10.1016/j.clsr.2007.11.004

Kiesler, S., Siegel, J., \& McGuire, T. W. (1984). Social psychological-aspects of computer-mediated communication. American Psychologist, 39(10), 1123-1134. doi: 10.1037//0003-066x.39.10.1123

Klettke, B., Hallford, D. J., \& Mellor, D. J. (2014). Sexting prevalence and correlates: A systematic literature review. Clinical Psychology Review, 34(1), 44-53. doi: 10.1016/ j.cpr.2013.10.007

Martinsen, T. J. (2016). Der blodet bruser og ting skjer. Master's thesis. Lillehammer: Inland Norway University of Applied Sciences.

Mascheroni, G., Vincent, J., \& Jimenez, E. (2015). 'Girls are addicted to likes so they post semi-naked selfies': Peer mediation, normativity and the construction of identity online. Cyberpsychology: Journal of Psychosocial Research on Cyberspace, 9(1), article 5. doi: 10.5817/CP2015-1-5

McKenna, K. Y. A., \& Bargh, J. A. (2000). Plan 9 from cyberspace: The implications of the internet for personality and social psychology. Personality and Social Psychology Review, 4(1), 57-75. doi: 10.1207/s15327957pspr0401_6

Parks, M. R., \& Floyd, K. (1996). Making friends in cyberspace. Journal of Communication, 46(1), 80-97. doi: 10.1111/j.1460-2466.1996.tb01462.x

Peter, J., Valkenburg, P. M., \& Schouten, A. P. (2006). Characteristics and motives of adolescents talking with strangers on the internet. CyberPsychology and Behaviour, 9(5), 526-530.

Renfrow, D. G., \& Rollo, E. (2014). Sexting on campus: Minimizing perceived risks and neutralizing behaviors. Deviant Behavior, 11(35), 903-920.

Ryltoft Terjesen, J. (2016). Straffeideologi i endring? En studie av vår tids straffeideologi, slik den kommer til uttrykk i kriminalpolitikken på voldtektsfeltet. Master's thesis, Faculty of Law, Institute of the Criminology and Sociology of Law, University of Oslo.

Sandberg, S. (2013). Are self-narratives strategic or determined, unified or fragmented? Reading Breivik's manifesto in light of narrative criminology. Acta Sociologica, 56(1), 69-83.

Siegel, J., Dubrovsky, V., Kiesler, S., \& McGuire, T. W. (1986). Group processes in computer-mediated communication. Organizational Behavior and Human Decision Processes, 37(2), 157-187. doi: 10.1016/0749-5978(86)90050-6

Staksrud, E. (2013). Online grooming legislation: Knee-jerk regulation? European Journal of Communication, 28(2), 152-167. doi: 10.1177/0267323112471304

Staksrud, Elisabeth, \& Olafsson, Kjartan. (2019). Tilgang, bruk, risiko og muligheter, Norske barn på Internett. Resultater fra EU Kids Online Undersøkelsen i Norge 2018 (s. 82). Oslo: Institutt for medier og kommunikasjon, Universitetet i Oslo. https://www.uio. 


\section{Elisabeth Fransson et al.}

no/english/research/strategic-research-areas/nordic/research/research-groups/living-thenordic-model/news/eu-kids-online-hovedrapport-for-norge-2019.pdf

Staksrud, E., Ólafsson, K., \& Livingstone, S. (2013). Does the use of social networking sites increase children's risk of harm? Computers in Human Behavior, 29(1), 40-50. doi: $10.1016 /$ j.chb.2012.05.026

Taylor, J. (2011). Policing social networking sites and online grooming. In J. Davidson \& P. Gottschalk (Eds.), Internet child abuse: Current research and policy (pp. 126-152). Abingdon, UK: Routledge.

United Nations. (1989). UN Convention on the Rights of the Child entry into force, 2 September 1990, in accordance with article 49. Retrieved from www2.ohchr.org/english/ law/crc.htm

Van Ouytsel, J., Walrave, M., Ponnet, K., \& Heirman, W. (2015). The association between adolescent sexting, psychosocial difficulties, and risk behavior: Integrative review. Journal of School Nursing, 31(1), 54-69. doi: 10.1177/1059840514541964

Walther, J. B. (1996). Computer-mediated communication. Communication Research, 23 (1), 3-43. doi: 10.1177/009365096023001001

Widerberg, K. (2001). Historien om et kvalitativt forskningsprosjekt. Oslo: Universitetsforlaget.

Wolak, J., Finkelhor, D., \& Mitchell, K. J. (2012). How often are teens arrested for sexting? Data from a national sample of police cases. Pediatrics, 129, 4-12.

Wolak, J., Finkelhor, D., Mitchell, K. J., \& Ybarra, M. L. (2008). Online 'predators' and their victims. American Psychologist, 63(2), 111-128.

Ybarra, M. L., Espelage, D. L., \& Mitchell, K. J. (2007). The co-occurrence of internet harassment and unwanted sexual solicitation victimization and perpetration: Associations with psychosocial indicators. Journal of Adolescent Health, 41(6), S31-S41. 